\title{
Europe-wide outbreaks of common voles in 2019
}

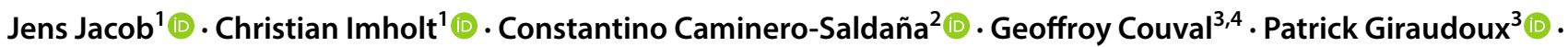

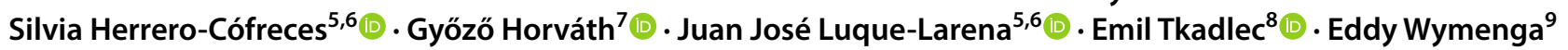

Received: 27 September 2019 / Revised: 13 January 2020 / Accepted: 20 January 2020 / Published online: 28 January 2020

(c) The Author(s) 2020

\begin{abstract}
Common voles (Microtus arvalis) are widespread in the European agricultural landscape from central Spain to central Russia. During population outbreaks, significant damage to a variety of crops is caused and the risk of pathogen transmission from voles to people increases. In 2019, increasing or unusually high common vole densities have been reported from several European countries. This is highly important in terms of food production and public health. Therefore, authorities, extension services and farmers need to be aware of the rapid and widespread increase in common voles and take appropriate measures as soon as possible. Management options include chemical and non-chemical methods. However, the latter are suitable only for small and valuable crops and it is recommended to increase efforts to predict common voles outbreaks and to develop and field test new and optimized management tools.
\end{abstract}

Keywords Microtus arvalis $\cdot$ Rodent-borne diseases $\cdot$ Rodent management $\cdot$ Rodent outbreaks $\cdot$ Rodent damage

\section{Key message}

- Common vole populations are synchronously rising in several countries indicating a massive European-wide outbreak.

- Non-chemical management options for the protection of large-scale crops are scarce and insufficient in agriculture and forestry.

- Significant damage by common voles in 2019 to crops and negative effects on human health are likely.

Communicated by M. Traugott.

Jens Jacob

jens.jacob@julius-kuehn.de

1 Julius Kuehn Institute, Federal Research Centre for Cultivated Plants, Institute for Plant Protection in Horticulture and Forests, Vertebrate Research, Toppheideweg 88, 48161 Muenster, Germany

2 Área de Plagas, Instituto Tecnológico Agrario de Castilla y León, Ctra. Burgos Km 119, 47071 Valladolid, Spain

3 Chrono-environment, UMR UFC/CNRS 6249 aff. INRA, Université de Bourgogne Franche-Comté, Besançon, France

4 FREDON Franche-Comté, Ecole-Valentin, France
- Authorities, extension services and farmers need to be aware of the rapid and widespread increase in common voles.

\section{Introduction}

Common voles (Microtus arvalis) are the most widespread vertebrate species in the European agricultural landscape (Heroldová et al. 2007), where they mostly inhabit grassland habitats. They are a main food source for a variety of predators and provide important ecosystems services including seed dispersal, soil aeration and fertilization (Jacob et al. 2014). However, during population

5 Dpto. Ciencias Agroforestales, ETSIIAA, Universidad de Valladolid, Avda. de Madrid 44, 34004 Palencia, Spain

6 Instituto Universitario de Investigación en Gestión Forestal Sostenible, Palencia, Spain

7 Department of Ecology, Faculty of Sciences, University of Pécs, Ifjúság Str. 6, Pecs 7624, Hungary

8 Department of Ecology and Environmental Sciences, Faculty of Science, Palacký University Olomouc, Šlechtitelů 27, 78371 Olomouc, Czech Republic

9 Altenburg \& Wymenga Ecological Consultants, Súderwei 2, 9269 TZ Feanwâlden, The Netherlands 
outbreaks that occur generally in a cyclic manner about every 3-5 years (Tkadlec and Stenseth 2001; Cornulier et al. 2013), populations can reach densities of $>2000$ individuals per hectare (Bryja et al. 2001), which leads to enormous damage to millions of hectares of agricultural and forestry crops in the European Union (EU) (Lambin et al. 2006; Luque-Larena et al. 2013).

Rodents can harbour and transmit a variety of pathogens to humans, livestock and companion animals (Meerburg et al. 2009). In common voles such pathogens include Francisella tularensis (Luque-Larena et al. 2017; Jeske et al. 2019), Staphylococcus aureus (Mrochen et al. 2018), Leptospira spp (Fischer et al. 2018), Echinococcus multilocularis (Delattre et al. 1988; Guerra et al. 2014) and Borrelia spp. (Tkadlec et al. 2019) which all can cause serious symptoms in humans, with associated costs assumed to reach billions of Euros worldwide (Carabin et al. 2005; Budke et al. 2006).

Farmers in most countries of the EU use rodenticides to protect their crops. Products with anticoagulant rodenticidal compounds (delayed action) are not available anymore in most countries of the EU for plant protection purposes, except for bromadiolone in France, the Netherlands and Romania and difenacoum in Portugal. Compounds that generate phosphine gas (acute action) are approved in all EU countries (Jacob and Buckle 2018). Common vole populations can sooner or later recover from acute rodenticide treatments (Hein and Jacob 2016) as it is the case in other small rodent species (Berny et al. 2018). Alternatives to chemical or agrotechnical [e.g. ploughing (Heroldová et al. 2007)] approaches for common vole management include repellents (Fischer et al. 2013; Hansen et al. 2017), traps (Schloetelburg et al. 2019), fence systems (Walther and Fuelling 2010) and controlled flooding of grasslands (Wymenga et al. 2016), but none of them is suitable for large-scale agricultural fields. Although often advocated, clear, quantitative experimental evidence that bio-control with predatory birds can reduce rodent populations or rodent damage is lacking (Labuschagne et al. 2016).

Spatially synchronous fluctuations are well-documented features of rodent populations (Ranta et al. 1999). Local and regional synchrony can occur through dispersal of individuals between populations (Liebhold et al. 2004) or the effect of mobile predators exerting similar predatory pressure on different populations (Bjornstad 2000). Large scale, even continental-wide, synchronization in dynamics is most likely reflecting similar environmental variability, termed the "Moran Effect" first introduced by Moran (1953).

\section{Materials and methods}

Measurements of common vole abundance or common vole activity indices were conducted in 2016-2019 in the Czech Republic, France, Germany, Hungary, Spain and the Netherlands. Measurements of activity were conducted in spring, summer and autumn in most years/countries and reflect abundance. The indices were weighted and then standardized (Z-transformation) for comparative reasons.

Common vole abundances were monitored by different methods. In the Czech Republic, a burrow index was measured by the number of active burrow entrances in alfalfa, clover and permanent grasslands (Tkadlec et al. 2019) in agricultural habitat across the country that resulted in counts per hectare. In France, common vole presence/absence (droppings, cut grass in fresh corridors, etc.) was recorded in the Franche-Comté region along transects in grasslands and the ratio of positive 10-pace intervals and the total number of 10-pace intervals was calculated (Delattre et al. 1999). In Germany, snap trapping was conducted in grasslands in the central German province of Thuringia following a standard protocol (Drewes et al. 2016) and results were converted to number of common voles per 100 trap nights. In southern Hungary, voles were live-trapped in alfalfa crops in the region of Southern Transdanubia and results were converted to individuals per 100 trap nights. In Spain two separate datasets from the same region were available; in both cases (termed E1 and E2) voles were trapped with live traps (converted to individuals per 100 trap nights) in alfalfa, cereals, fallows and their margins in the Castilla-y-León region (Rodriguez-Pastor et al. 2016). In the Netherlands, common voles were monitored in grassland on peat and clay soils in the province of Friesland by counting tunnel entrances and results were converted to number of tunnel entrances per $\mathrm{m}^{2}$.

\section{Results}

In the Czech Republic, Germany, Spain and the Netherlands increases of common vole populations were considerable compared to previous years (Fig. 1). These were particularly pronounced in the Czech Republic, Spain and the Netherlands where common vole abundances in summer of 2019 were 2.4-fold (Czech Republic), 7.4-fold (E1), 3.3-fold (E2, both Spain) and 5.9-fold (The Netherlands) compared to the mean abundance from spring of 2016 to spring of 2019. In Germany and Hungary, the abundances in summer of 2019 were approximately twofold the mean abundance from spring of 2016 to spring of 2019 (Table 1). In France common vole abundance continued to be low after a period of generally low vole abundance that followed the last outbreak in 2016. 

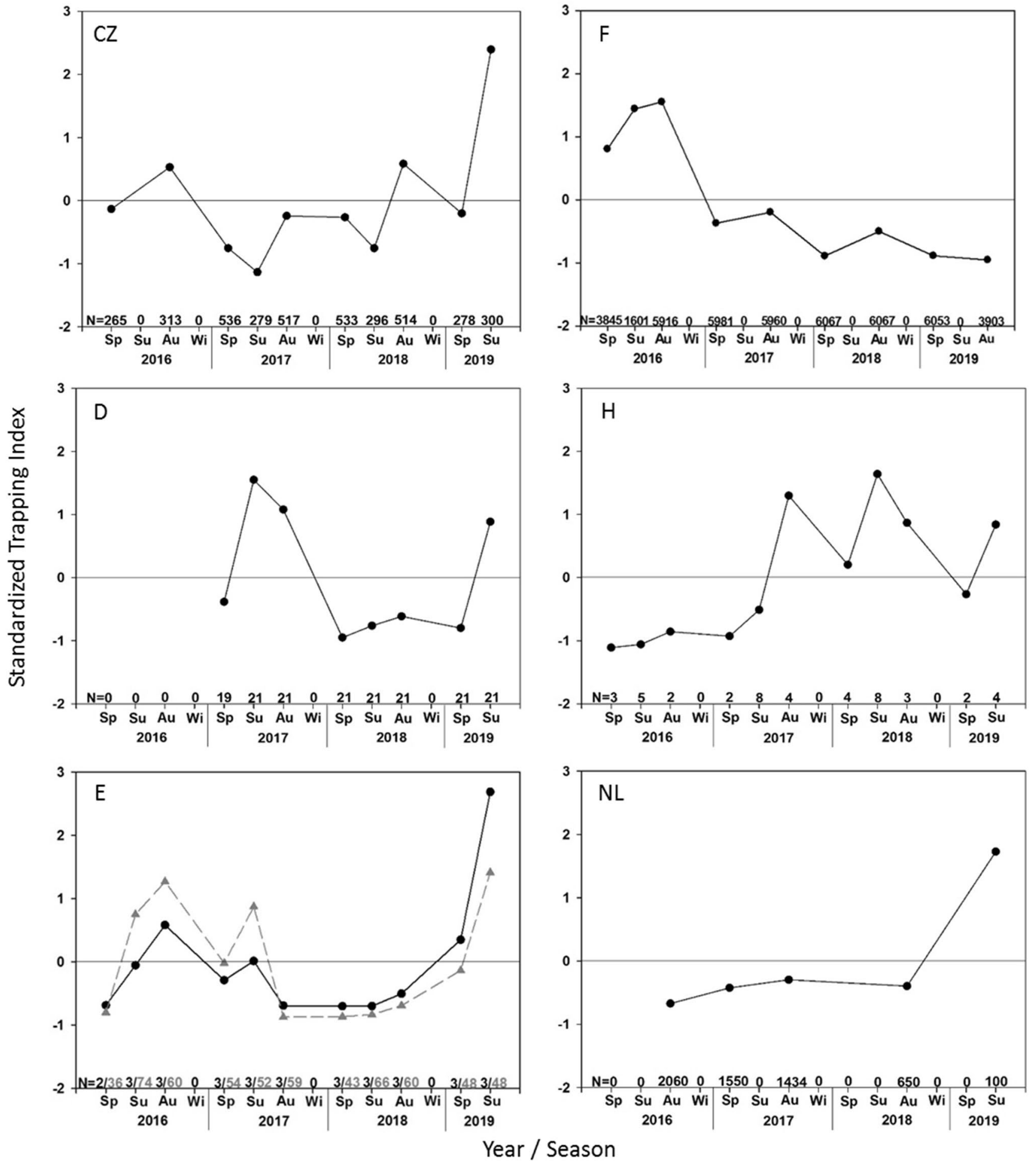

Fig. 1 Z-transformed common vole abundance indices per country per season from spring of 2016 to summer of 2019 (solid line represents mean of period). The $x$ axis shows the number $(N)$ of monitoring sites per season ( $S p$ spring, $S u$ summer, $A u$ autumn, $W i$ winter)

In addition to monitoring data, there are unquantified reports from countries including Austria [pers. comm. M. Weinhappel, Chamber of Agriculture Lower Austria; (Die and year. Different monitoring methods were used (for details see text). $C Z$ Czech Republic, $F$ France, $D$ Germany, $H$ Hungary, $E$ Spain $[\mathrm{E} 1=$ Circle $($ black$), \mathrm{E} 2=$ Triangle $($ grey $)], N L$ Netherlands

Presse 2019)], Belgium [pers. comm. K. Baert, Research Institute Nature and Forest; (Smets 2019)], Poland (Z. Borowski, Forest Research Institute) and Switzerland (pers. 
Table 1 Common vole abundance indices for summer 2019 across plots per country and mean from spring 2016 to spring 2019 across years per country \pm SE

\begin{tabular}{lrrrrrr}
\hline & Czech Republic & Germany & Hungary & \multicolumn{2}{l}{ Spain } & \multirow{2}{*}{ The Netherlands } \\
\cline { 3 - 5 } & & & & E1 & \\
\hline Summer 2019 & $1014 \pm 98$ & $14 \pm 3.4$ & $9.5 \pm 1.4$ & $52 \pm 17$ & $23.9 \pm 11.9$ & $5.9 \pm 4.9$ \\
Spring 2016-spring 2019 & $426 \pm 40$ & $6 \pm 2.5$ & $5 \pm 1.4$ & $7 \pm 2.2$ & $7.3 \pm 8.7$ & $1 \pm 0.2$ \\
\hline
\end{tabular}

Different monitoring methods were used (for details see text) comm. B. Beuret, Fondation Rurale Interjurassienne) that also indicate a pan-European increase in common vole abundance in 2019.

\section{Discussion}

Monitoring data and anecdotal evidence from ten European countries indicate that synchronous population outbreaks of common voles are occurring in many countries. This is of concern because high population densities of this species cause devastating damage to many crops (e.g. BabinskaWerka 1979) and they can pose considerable zoonotic disease risks (Meerburg et al. 2009; Luque-Larena et al. 2017).

The concept of spatial synchronization in populations has received attention for many decades, but continental-wide phase-locking dynamics of spatially separated populations remain poorly understood. The presented data indicate such an overall trend for the common vole in Europe, though the manifestation of this effect can differ between spatial scales and might reflect local drivers like landscape or agricultural practices that were not considered in this study. Nevertheless, our knowledge on rodent ecology is substantially increased when monitoring data are compared among countries (Cornulier et al. 2013). Coordination of monitoring programs among European countries and predictive tools could help refine pest management.

Despite many changes in cropping systems, particularly in land use intensity, choice of crops, fragmentation, mechanization, climate, etc., the general patterns of common vole outbreaks such as frequency and amplitude range have not changed drastically (see Delattre et al. 1992). There are very few examples of outbreaks spreading to areas where they did not occur in the past (Van Wijngaarden 1957; Luque-Larena et al. 2013; Jareño et al. 2014). This indicates that common vole outbreaks are inherent to the European agricultural landscape similar to lemming outbreaks in northern Europe.

Pest rodent management needs to balance management, social and environmental needs. It is most effective when early action is taken (Singleton et al. 2003). This requires that farmers are well informed of outbreak risks or population build up and are aware of the appropriate ways for monitoring of vole abundance and/or forecast tools. This could also benefit other studies and management of other rodent species because there is considerable co-variance of spatio-temporal dynamics among rodent species (Carslake et al. 2011). Studies show that landscape and soil properties are linked to the general occurrence of common vole outbreaks (Delattre et al. 1992, 1999; Blank et al. 2011). In addition, weather conditions with a time lag of several months are related to outbreak risk (Imholt et al. 2011; Esther et al. 2014) and can be used for regional predictions for annual and perennial crops (Esther et al. 2014; Giraudoux et al. 2017) in many areas. However, so far forecast systems are specific for particular regions (Giraudoux et al. 2019) and cannot be used at the national let alone at the European scale.

During the last 10-15 years, there was a major decrease in the availability of chemical management options for common voles and other agricultural rodent pest species across the EU (Jacob and Buckle 2018). Therefore, it is increasingly difficult for farmers to manage rodent populations to prevent massive increases in abundance and the associated crop damage. New restrictions on use of zinc phosphide have been imposed recently by German and Czech authorities that make chemical management impossible in most regions where outbreaks occur. Generally, there are some preventative and non-chemical methods available. However, none of these are unconditionally effective, practicable and environmentally safe. For instance, bio-control, repellents and diversion feeding were considered ineffective by German farmers (an der Heiden et al. 2017). This leaves agrotechnical measures (e.g. ploughing) as the sole tool to reduce vole numbers. In the Dutch province of Friesland, farmers started to flood vole-infested grasslands and developed innovative techniques to cover large areas with reasonable input of labour and costs. Non-chemical techniques such as repellents are rarely tested (or effective) in management, let alone in realistic field scenarios (Hansen et al. 2016). The same is true for bio-control with avian predators (Labuschagne et al. 2016).

Some existing non-chemical methods that are supposed to be effective such as ploughing and keeping vegetation of margins low are as a whole antagonistic to soil and biodiversity conservation (Garcia-Orenes et al. 2009). In southern regions of Europe, such as Spain, the use of fire, which is completely regulated by law, is commonly claimed by farmers as an effective weed and vole managing tool, though scientific evidence on the efficiency is lacking. Fertility 
control of rodents has been tested using hormones, plant compounds, immuno-contraception and other techniques (Jacob 2008), but there are no registered products available in the EU and some of them are likely to be problematic (practicability, efficiency, biological risks, ethics) if applied on a large scale.

Following the concept of ecologically based rodent management, which values the important role of voles for biodiversity and ecosystem services, alternative methods, either alone or in combination, should be tested thoroughly in field trials to obtain robust information about efficacy, environmental and ecological impact, and benefit-cost ratios. In addition, existing chemical and non-chemical methods should be optimized and new techniques developed to be added to the existing (small) tool box. Such an integrated approach has proved to be effective and costefficient for the water vole (Arvicola terrestris), a grassland species living in the same habitat as the common vole (Giraudoux et al. 2017).

The decreased availability of chemical methods and the lack of suitable and/or tested non-chemical methods leave farmers running integrated or organic farms with few options for common vole control other than physical barriers and trapping that are unsuitable for application in large-scale cropping. This is a major concern given the massive damage and yield loss caused by common vole outbreaks in many countries of the EU and health implications due to the transmission of zoonotic pathogens from voles to people. Despite their ecological importance, common vole outbreaks are a real burden to European societies and economies and require solutions from and supported by research, administrations and policy makers.

We emphasize that there are major common vole outbreaks occurring in many countries of Europe and therefore appropriate management strategies are urgently needed. Investment in research and development is required for management of the current and future common vole outbreaks. History shows that common vole outbreaks will not go away.

\section{Author contributions}

JJ conceived the idea. CI, GH, ET, EW, PG, SHC, JJLL and CCS provided data. All authors wrote, read and approved the manuscript.

Acknowledgements Open Access funding provided by Projekt DEAL. The authors thank Aurélien Levret and Dominique Rieffel for their help in the field, María Carmen García Ariza for her assistance in coordinating field works and the Zone atelier Arc Jurassien for various support (https://zaaj.univ-fcomte.fr).

\section{Compliance with ethical standards}

Conflict of interest The authors declare that there is no conflict of interest.

Ethical approval Relevant animal ethics permission were issued for work in Germany (22-2684-04-15-105/16), Spain (Ethical Committee University of Valladolid (CEEBA), authorization code: 4801646), SHC, JJLL and CCS held official trapping permits from DGMN, Junta de Castilla y León, as well as national certificates (B and C categories) to manipulate animals for research.

Open Access This article is licensed under a Creative Commons Attribution 4.0 International License, which permits use, sharing, adaptation, distribution and reproduction in any medium or format, as long as you give appropriate credit to the original author(s) and the source, provide a link to the Creative Commons licence, and indicate if changes were made. The images or other third party material in this article are included in the article's Creative Commons licence, unless indicated otherwise in a credit line to the material. If material is not included in the article's Creative Commons licence and your intended use is not permitted by statutory regulation or exceeds the permitted use, you will need to obtain permission directly from the copyright holder. To view a copy of this licence, visit http://creativecommons.org/licenses/by/4.0/.

\section{References}

an der Heiden A, Plekat A, Wolff C, Jacob J (2017) Umweltverträgliche Nagetier-Bekämpfung in der Landwirtschaft: Vergleichende Umweltbewertung für Rodentizide, Bewertung nicht-chemischer Alternativen/Ecologically benign rodent management in agriculture: comparative assessment of rodenticide use and alternatives. In: ResearchGate. https://www.researchgate.net/publication/32105 7285_Umweltvertragliche_Nagetier-Bekampfung_in_der_Landw irtschaft_Vergleichende_Umweltbewertung_fur_Rodentizide_ Bewertung_nicht-chemischer_Alternativen_Ecologically_benig n_rodent_management_in_agriculture_. Accessed 18 Sept 2019

Babinska-Werka J (1979) Effects of common vole on alfalfa crop. Acta Theriol (Warsz) 24:281-297. https://doi.org/10.4098/ AT.arch.79-29

Berny P, Esther A, Jacob J, Prescott C (2018) Development of resistance to anticoagulant rodenticides in rodents. In: van den Brink NW, Elliott JE, Shore RF, Rattner BA (eds) Anticoagulant rodenticides and wildlife. Springer, pp 259-286

Bjornstad ON (2000) Cycles and synchrony: two historical "experiments" and one experience. J Anim Ecol 69:869-873. https://doi. org/10.1046/j.1365-2656.2000.00444.x

Blank BF, Jacob J, Petri A, Esther A (2011) Topography and soil properties contribute to regional outbreak risk variability of common voles (Microtus arvalis). Wildl Res 38:541-550

Bryja J, Tkadlec E, Nesvadbova J, Gaisler J, Zejda J (2001) Comparison of enumeration and Jolly-Seber estimation of population size in the common vole Microtus arvalis. Acta Theriol (Warsz) 46:279-285. https://doi.org/10.1007/BF03192434

Budke CM, Deplazes P, Torgerson PR (2006) Global socioeconomic impact of cystic echinococcosis. Emerg Infect Dis 12:296-303

Carabin H, Budke CM, Cowan LD, Willingham AL, Torgerson PR (2005) Methods for assessing the burden of parasitic zoonoses: echinococcosis and cysticercosis. Trends Parasitol 21:327-333. https://doi.org/10.1016/j.pt.2005.05.009

Carslake D, Cornulier T, Inchausti P, Bretagnolle V (2011) Spatio-temporal covariation in abundance between the cyclic common vole 
Microtus arvalis and other small mammal prey species. Ecography 34:327-335. https://doi.org/10.1111/j.1600-0587.2010.06334.x

Cornulier T, Yoccoz NG, Bretagnolle V, Brommer JE, Butet A, Ecke F, Elston DA, Framstad E, Henttonen H, Hörnfeldt B (2013) Europewide dampening of population cycles in keystone herbivores. Science 340:63-66

Delattre P, Pascal M, Lepesteur M, Giraudoux P, Damange J (1988) Ecological and epidemiological characteristics of Echinococcusmultilocularis during a complete population-cycle in a secondary host (Microtus arvalis). Can J Zool Rev Can Zool 66:2740-2750. https://doi.org/10.1139/z88-401

Delattre P, Giraudoux P, Baudry J, Musard P, Toussaint M, Truchetet D, Stahl P, Poule ML, Artois M, Damange J-P (1992) Land use patterns and types of common vole (Microtus arvalis) population kinetics. Agric Ecosyst Environ 39:153-168

Delattre P, De Sousa B, Fichet-Calvet E, Quere JP, Giraudoux P (1999) Vole outbreaks in a landscape context: evidence from a six year study of Microtus arvalis. Landsc Ecol 14:401-412. https://doi. org/10.1023/A:1008022727025

Die Presse (2019) Mäuseplage bringt Ernte im Weinviertel in Gefahr. In: Presse. https://diepresse.com/home/panorama/oesterreic h/5664914/Maeuseplage-bringt-Ernte-im-Weinviertel-in-Gefah r. Accessed 18 Sept 2019

Drewes S, Schmidt S, Jacob J, Imholt C, Ulrich RG (2016) APHAEA/ EWDA species card: voles and mouses. https://www.aphaea.org/ cards/species/voles. Accessed 18 Sept 2019

Esther A, Imholt C, Perner J, Schumacher J, Jacob J (2014) Correlations between weather conditions and common vole (Microtus arvalis) densities identified by regression tree analysis. Basic Appl Ecol 15:75-84

Fischer D, Imholt C, Prokop A, Jacob J (2013) Efficacy of methyl nonyl ketone as an in-soil repellent for common voles (Microtus arvalis). Pest Manag Sci 69:431-436. https://doi.org/10.1002/ps.3426

Fischer S, Mayer-Scholl A, Imholt C, Spierling NG, Heuser E, Schmidt S, Reil D, Rosenfeld UM, Jacob J, Nöckler K (2018) Leptospira genomospecies and sequence type prevalence in small mammal populations in Germany. Vector-Borne Zoonotic Dis 18:188-199

Garcia-Orenes F, Cerda A, Mataix-Solera J, Guerrero C, Bodi MB, Arcenegui V, Zornoza R, Sempere JG (2009) Effects of agricultural management on surface soil properties and soil-water losses in eastern Spain. Soil Tillage Res 106:117-123. https:// doi.org/10.1016/j.still.2009.06.002

Giraudoux P, Couval G, Levret A, Mougin D, Delavelle A (2017) A long-term study of European water vole population outbreaks reveals that integrated control is possible. Fourrages 230:169-176

Giraudoux P, Villette P, Quéré J-P, Damange J-P, Delattre P (2019) Weather influences $M$. arvalis reproduction but not population dynamics in a 17-year time series. Sci Rep 9:13942. https://doi. org/10.1038/s41598-019-50438-z

Guerra D, Hegglin D, Bacciarini L, Schnyder M, Deplazes P (2014) Stability of the southern European border of Echinococcus multilocularis in the Alps: evidence that Microtus arvalis is a limiting factor. Parasitology 141:1593-1602. https://doi.org/10.1017/ S0031182014000730

Hansen SC, Stolter C, Imholt C, Jacob J (2016) Plant secondary metabolites as rodent repellents: a systematic review. J Chem Ecol 42:970-983. https://doi.org/10.1007/s10886-016-0760-5

Hansen SC, Stolter C, Imholt C, Jacob J (2017) Like or dislike: response of rodents to the odor of plant secondary metabolites. Integr Zool 12:428-436. https://doi.org/10.1111/1749-4877.12245

Hein S, Jacob J (2016) Recovery of common vole populations (Microtus arvalis) after rodenticide application. In: 60 German plant protection conference-short presentations of lectures and posters, pp 495-495
Heroldová M, Bryja J, Zejda J, Tkadlec E (2007) Structure and diversity of small mammal communities in agriculture landscape. Agric Ecosyst Environ 120:206-210

Imholt C, Esther A, Perner J, Jacob J (2011) Identification of weather parameters related to regional population outbreak risk of common voles (Microtus arvalis) in Eastern Germany. Wildl Res 38:551-559

Jacob J (2008) Response of small rodents to manipulations of vegetation height in agro-ecosystems. Integr Zool 3:3-10. https://doi.org /10.1111/j.1749-4877.2008.00078.x

Jacob J, Buckle A (2018) Use of anticoagulant rodenticides in different applications around the world. In: van den BrinkNW, ElliottJE, Shore RF,Rattner BA (eds) Anticoagulant rodenticides and wildlife. Springer, pp 11-43

Jacob J, Manson P, Barfknecht R, Fredricks T (2014) Common vole (Microtus arvalis) ecology and management: implications for risk assessment of plant protection products. Pest Manag Sci 70:869878. https://doi.org/10.1002/ps.3695

Jareño D, Viñuela J, Luque-Larena JJ, Arroyo L, Arroyo B, Mougeot F (2014) A comparison of methods for estimating common vole (Microtus arvalis) abundance in agricultural habitats. Ecol Indic 36:111-119

Jeske K, Tomaso H, Imholt C, Schulz J, Beerli O, Suchomel J, Heroldova M, Jacob J, Staubach C, Ulrich RG (2019) Detection of Francisella tularensis in three vole species in Central Europe. Transbound Emerg Dis 66:1029-1032. https://doi.org/10.1111/ tbed.13078

Labuschagne L, Swanepoel LH, Taylor PJ, Belmain SR, Keith M (2016) Are avian predators effective biological control agents for rodent pest management in agricultural systems? Biol Control 101:94-102. https://doi.org/10.1016/j.biocontrol.2016.07.003

Lambin X, Bretagnolle V, Yoccoz NG (2006) Vole population cycles in northern and southern Europe: is there a need for different explanations for single pattern? J Anim Ecol 75:340-349. https:// doi.org/10.1111/j.1365-2656.2006.01051.x

Liebhold A, Koenig WD, Bjornstad ON (2004) Spatial synchrony in population dynamics. Annu Rev Ecol Evol Syst 35:467-490. https ://doi.org/10.1146/annurev.ecolsys.34.011802.132516

Luque-Larena JJ, Mougeot F, Vinuela J, Jareno D, Arroyo L, Lambin X, Arroyo B (2013) Recent large-scale range expansion and outbreaks of the common vole (Microtus arvalis) in NW Spain. Basic Appl Ecol 14:432-441. https://doi.org/10.1016/j. baae.2013.04.006

Luque-Larena JJ, Mougeot F, Arroyo B, Dolors Vidal M, RodriguezPastor R, Escudero R, Anda P, Lambin X (2017) Irruptive mammal host populations shape tularemia epidemiology. PLoS Pathog 13:e1006622. https://doi.org/10.1371/journal.ppat.1006622

Meerburg BG, Singleton GR, Kijlstra A (2009) Rodent-borne diseases and their risks for public health. Crit Rev Microbiol 35:221-270. https://doi.org/10.1080/10408410902989837

Moran P (1953) The statistical analysis of the Canadian lynx cycle. 2. Synchronization and meteorology. Aust J Zool 1:291-298. https ://doi.org/10.1071/ZO9530291

Mrochen DM, Schulz D, Fischer S, Jeske K, El Gohary H, Reil D, Imholt C, Trübe P, Suchomel J, Tricaud E (2018) Wild rodents and shrews are natural hosts of Staphylococcus aureus. Int J Med Microbiol IJMM 308:590

Ranta E, Kaitala V, Lindstrom J (1999) Spatially autocorrelated disturbances and patterns in population synchrony. Proc R Soc B Biol Sci 266:1851-1856. https://doi.org/10.1098/rspb.1999.0856

Rodriguez-Pastor R, Jose Luque-Larena J, Lambin X, Mougeot F (2016) "Living on the edge": the role of field margins for common vole (Microtus arvalis) populations in recently colonised Mediterranean farmland. Agric Ecosyst Environ 231:206-217. https://doi.org/10.1016/j.agee.2016.06.041 
Schloetelburg A, Plekat A, Bellingrath-Kimura S, Jacob J (2019) Self-service traps inspected by avian and terrestrial predators as a management option for rodents. Pest Manag Sci. https://doi. org/10.1002/ps.5550

Singleton GR, Sudarmaji Tuan NP, Sang PM, Huan NH, Brown PR, Jacob J, Heong KL, Escalada MM (2003) Reduction in chemical use following integrated ecologically based rodent management. Int Rice Res Notes 28:33-35

Smets P (2019) 2019 is topjaar voor veldmuizen, en daardoor ook voor uilen. In: Natuurpunt. https://www.natuurpunt.be/nieuws/2019topjaar-voor-veldmuizen-en-daardoor-ook-voor-uilen-20190802. Accessed 18 Sept 2019

Tkadlec E, Stenseth NC (2001) A new geographical gradient in vole population dynamics. Proc R Soc Lond B Biol Sci 268:1547-1552

Tkadlec E, Vaclavik T, Siroky P (2019) Rodent host abundance and climate variability as predictors of tickborne disease risk 1 year in advance. Emerg Infect Dis 25:1738-1741. https://doi.org/10.3201/ eid2509.190684
Van Wijngaarden A (1957) The rise and disappearance of continental vole plague zones in the Netherlands. Staatsdrukkerij Uitgeverijbedrijf

Walther B, Fuelling O (2010) Vole trapping fences-a new approach to migration barriers. In: Föko eV (ed) Proceedings to the 14th international conference on cultivation technique and phytopathological problems in organic fruit-growing, 22-24 February 2010, Hohenheim, Germany. pp 341-345

Wymenga E, Latour J, Beemster N, Bos D, Bosma N, Haverkamp J, Hendriks R, Roerink GJ, Kasper GJ, Roelsma J, Scholten S, Wiersma P, van der Zee E (2016) Terugkerende muizenplagen in Nederland. Inventarisatie, sturende factoren en beheersingrecurring vole outbreaks in The Netherlands. Feanwâlden

Publisher's Note Springer Nature remains neutral with regard to jurisdictional claims in published maps and institutional affiliations. 